\title{
Evaluation of a Global Talent Information System (A Case Study of Global Talent Program at ABC Company)
}

\author{
Indrawati and Lely Melia Kaniawati
}

\begin{abstract}
Evaluation of an information system is an assessment of the information system effectiveness including an identification of obstacles and barriers of the system information implementation. The purpose of this study was to evaluate the implementation of the Information System of Global Talent by using modification of Updated DeLone and Mclean Information System Success Model. To test the purpose model, this study collected data by using purposive sampling technique and able to gather data from 300 respondents. The collected data was analysed by using SmartPLS software version 2.0. The results showed that System Quality, Information Quality and Management Support have positive and significant effect on System Use $\left(R^{2}\right.$ $=92.6 \%)$ and System Use has positive and significant effect on User Satisfaction $\left(R^{2}=87.6 \%\right)$.
\end{abstract}

Index Terms-Evaluation, information system, delone \& mclean, updated DM IS success model.

\section{INTRODUCTION}

$\mathrm{ABC}$ company is a dominant telecom player in Indonesia which recently aggressively starting its international expansion program with the target to have 10 (ten) footprint countries in the region. Hoping of gaining and sustaining the competitive advantages in the years ahead, ABC company beliefs that to compete, to win the competition and achieve challenging business goal with global player not only in regional market but also in Indonesian market, it has to have a systematic yet comprehensive human capital development program with creating great leader and great people with international experience and certification [1]. The quality of global leaders and employees are prepared through several program and one of the program is the Global Talent Program (GTP). GTP is based Competence Development Policy. This policy was explained that GTP is a special assignment to employees to be formed into Great People.

In the implementation of GTP, the Company uses a holistic method of learning called blended learning. This method is defined as a form of teaching that thorough use of all five senses of human beings. In its application, the Company split method of learning into three stages: Classroom Training, Mentoring, and Real Job Assignment. Every participant had to do a three months overseas job assignment, in order to provide them with sufficient yet real international business experiences. The overseas job assignments are mainly aim to support the ABC's

Manuscript received October 29, 2017; revised February 12, 2018

Indrawati and Lely Melia Kaniawati are with Faculty of Economics and Business, Telkom University, Bandung, Indonesia (e-mail: indrawati@telkomuniversity.ac.id, lelymelia@gmail.com). international expansion programs. Despite of its important for the company's future sustainability, the GTP involves hefty investment [2]. In the rule of GTP mentioned that during Overseas Real Job Assignment, the participant of GTP is required to use Information System of Global Talent. The usage of the Information System can become a key success factor of GTP.

Up to the beginning of this study, there is no evalution of the Information System of GTP, yet, especially the one that use modified updated DeLone and Mclean Information System Success Model. This lack of knowledge motivated the researchers to conduct this study. The Objective of this study was to measure the success of Information System used by GTP based on modified updated DeLone and Mclean Information System Success Model [3] The result of this study could be important to increase the performance of GTP Information System which could increase the success of GTP in creating Global Talents.

\section{LITERATUR REVIEW}

To achieve the objective as described in Section I. Introduction, some literature review of theories and models related to the information system success models are required. There are various IS success models that can be used to measure users' satisfaction on information system. This research applied the criteria of a good research model, namely importance, novelty, parsimony, level, and falsifiability [4]. Using those criteria, this research found that Updated DeLone and Mclean Information System Success Model as shown in Fig. 1 is the best model for this study. The model of DeLone and McLean is proposed in 1992 than revised in 2003 . They proposed that the quality of a system, the information quality, and service quality are the predictors of behavioral intention to use, system used and user satisfaction. Both the system used and user satisfaction have impacts on net benefits.

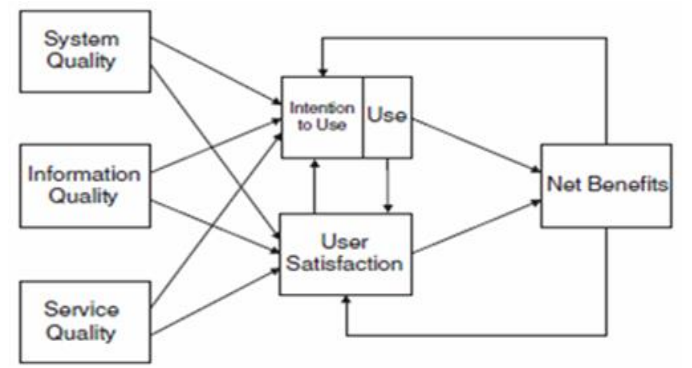

Fig. 1. Updated information success model by DeLone and McLean.

Tjandra, Indrawati, and Rahayu had used the Information Success Model by DeLone and McLean, but they modified 
the model by eliminated Intention to Use, Use, and benefit as shown in Fig. 2. They found that the model can substantially explained the variance in the user satisfaction in using an information system [5].

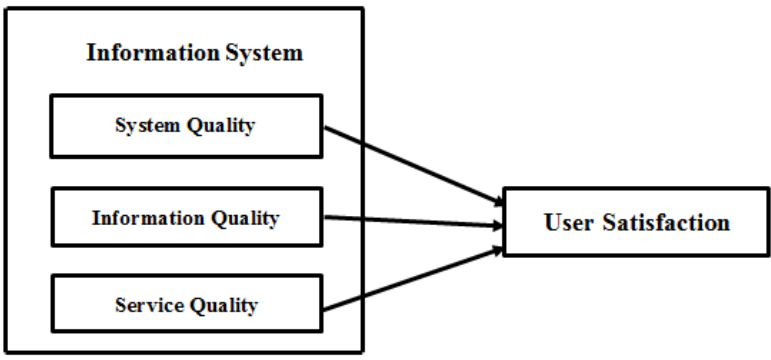

Fig. 2. Information system success model of Tjandra, Indrawati, and Rahayu [5].

The characteristics, social and economic background of respondents may influence the implementation of a model, a model that can be implemented well in a country or in a given situation might not be directly implemented in another country or situation [6]. Considering this matter, this study tried to fit the model with the condition of the respondents of this research. In this process, this study make in-depth interview with several participants of GTP. The result of indepth interview revealed that the factors important for evaluating GTP's information system are as shown in Fig. 3.

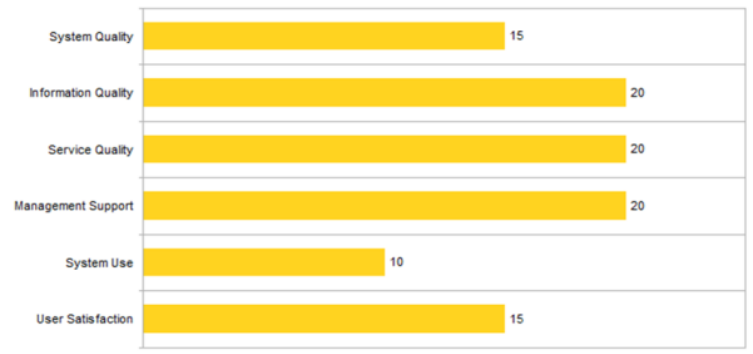

Fig. 3. In-depth interview result.

Using insight from the in-depth interview process, there is one variable which has not been included in Updated Information Success Model by DeLone and McLean, namely Management Support. Therefore, to make the model fit with the respondents' condition and situation, this study added Management Support to the model. The inclution of Management Support variable had ever been done in the research of Zaied [7] the different is in Zaied [7] the Management Support is mediating variable, which mediate the influence of Information Quality to Perceived Usefulness and Perceived Ease of Use as shown in Fig. 4.

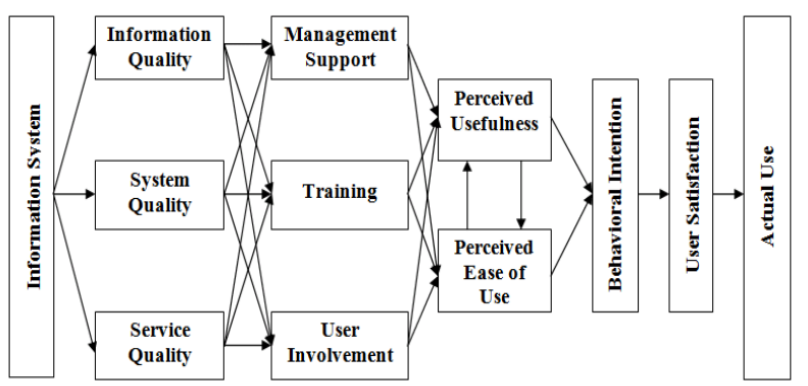

Fig. 4. Integrated success model [7].

In this study the inclusion of Management Support variable as the independent variable which influence System
Use, as shown in Fig. 5. Proposed Model of the Study.

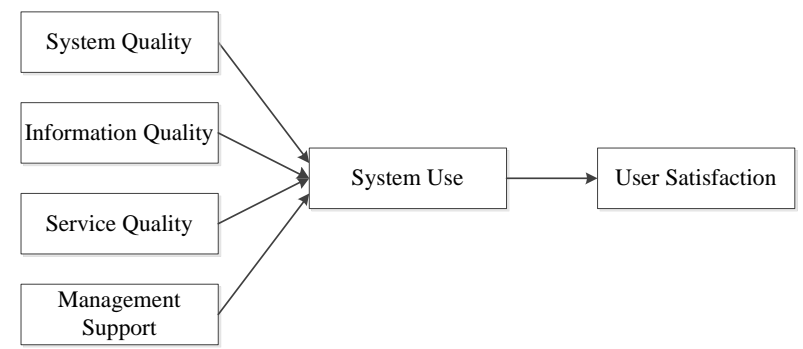

Fig. 5. Proposed model of the study.

Based on Fig. 5, there are four independent variables (System Quality, Information Quality, Service Quality, and Management Support) which directly influence the System Use as mediating variable, and the System Use influences the User Satisfaction.

System Quality (SyQ) measures the desired characteristics of the information system. Information Quality (IQ) concerned with how good is IS in terms of output. Service Quality (SvQ) is overall support delivered by the library, ICT support department and service provider such as blogger, social network sites, etc. System Use (SU) is the degree and manner in which user utilize the capabilities of an IS, and User satisfaction (US) is user's level of satisfaction with the IS (Delone \& McLean, 2003). Manajemen Support (MS) refers to management approval and continuous support not only during the IS project implementation but also throughout the operational phase of the system [7].

Based on the proposed model as shown in Fig. 4, the hypotheses that were tested in this study are as follow:

H1 : System Quality has a positive significant effect on System Use.

$\mathrm{H} 2$ : Information Quality has a positive significant effect on System Use.

H3 : Service Quality has a positive significant effect on System Use.

H4 : Management Support has a positive significant effect on System Use.

H5 : System Use has a positive significant effect on User Satisfaction.

\section{RESEARCH METHODOLOGY}

To test the hypotheses as written in Part II, this study collected data by using a set of questionnaire developed through four steps in order to fulfill good content, face, construct, and convergent validity. The first step is reviewing the items from existing relevant literature to make sure that item of questionnaire has good content validity and operationalized the construct. Table I shows the items used in this study.

TABLE I: ITEMS OF EACH VARIABLE

\begin{tabular}{|l|l|}
\hline Code & Items of System Quality \\
\hline SyQ1 & GTP Online is user friendly. \\
SyQ2 & It is easy for me to share the content on GTP Online. \\
SyQ3 & It is easy for me to post comments on GTP Online. \\
SyQ4 & GTP Online service is always available so I can use it \\
& whenever I want. \\
SyQ5 & It is easy to find the information I need from GTP Online. \\
SyQ6 & GTP Online website operate reliably. \\
\hline
\end{tabular}




\begin{tabular}{|c|c|}
\hline Code & Items of Information Quality \\
\hline $\begin{array}{l}\text { IQ3 } \\
\text { IQ4 } \\
\text { IQ5 } \\
\text { IQ6 }\end{array}$ & $\begin{array}{l}\text { Information is provided in a format which is useful for me. } \\
\text { The Information Systems provide output that is exactly } \\
\text { what you need, } \\
\text { I get the information I need in time. } \\
\text { I have more relevant, useful and significant information. } \\
\text { The systems provide accurate and clear information. } \\
\text { The information is not subject to misinterpretation and } \\
\text { discussions. }\end{array}$ \\
\hline IteCode & Items of Service Quality \\
\hline $\begin{array}{l}\text { SvQ3 } \\
\text { SvQ4 }\end{array}$ & $\begin{array}{l}\text { GTP Online give prompt service to users. } \\
\text { GTP Online understand and adapt to the user's specific } \\
\text { needs. } \\
\text { GTP Online can be dependent upon to provide what is } \\
\text { promised. } \\
\text { GTP Online are trustworthy. }\end{array}$ \\
\hline Code & Items of Management Support \\
\hline MS1 & $\begin{array}{l}\text { Management is aware of the benefits that can be achieved } \\
\text { with the use of the system. }\end{array}$ \\
\hline MS2 & $\begin{array}{l}\text { Management always supports and encourages the use of the } \\
\text { system for job-related work. }\end{array}$ \\
\hline MS3 & $\begin{array}{l}\text { Management provides most of the necessary help and } \\
\text { resources to enable people to use the system }\end{array}$ \\
\hline MS4 & $\begin{array}{l}\text { Management is really keen to see that people are happy } \\
\text { with using the system }\end{array}$ \\
\hline MS5 & $\begin{array}{l}\text { Management provides good access to hardware resources } \\
\text { when people need them }\end{array}$ \\
\hline MS6 & $\begin{array}{l}\text { Management provides good access to various types of } \\
\text { software when people need them }\end{array}$ \\
\hline Code & Items of System Use \\
\hline SU1 & Using GTP Online enables me to accomplish job's tasks \\
\hline SU2 & $\begin{array}{l}\text { Using GTP Online enables to perform work's requirements } \\
\text { more quickly }\end{array}$ \\
\hline SU3 & Using GTP Online improves my job performance \\
\hline SU4 & Using GTP Online in job increases my productivity \\
\hline SU5 & Using GTP Online enhances my effectiveness in the job \\
\hline Code & Items of User Satisfaction \\
\hline US1 & $\begin{array}{l}\text { I am satisfied that GTP Online meet my knowledge or } \\
\text { information processing needs }\end{array}$ \\
\hline US2 & I am satisfied with GTP Online efficiency \\
\hline US3 & I am satisfied with GTP Online effectiveness \\
\hline US4 & Overall, I am satisfied with GTP Online \\
\hline
\end{tabular}

Second step is asking for experts' and experienced academicians' comments and suggestions in order to have good face and content validity. The result of the second step was good comments from experts towards the items and the form of the questionnaire. Having this result, this study proceeded to the third step, readability test. The result of the third step revealed that the questionnaire is considered to be readable and easy to understand. The last step is pilot test that was done to prove that the questionnaire fulfills the construct validity and reliability [8]. For pilot test, this study was able to collect data from 30 GTP participants, this was done following Hair, Black, Babin, \& Anderson [9] who stated that pilot test can use a small convenience sample of respondents, while the size of samples is following Levine, Krehbiel, and Berenson [10] who stated that when the sample size is 30 and above the sampling distribution looks approximately. The result of pilot test showed that all the requirements of validity and reliability were fulfilled by all 31 items.

Having valid and reliable questionnaire, this study collected data from GTP participants through Google form, the link of questionnaire was distributed to participants by using email. This study was able to collect valid data from
300 respondents selected purposively. The collected data were analysed by using Smart PLS 2.0, a PLS software packages, that can be downloaded for free at http://www.smartpls.de.

\section{DATA ANALYSIS AND RESUlt}

Analysis using SmartPLS involves two steps (1) The Outer Model Test which is an asssessment of the measurement model to test the reliability and validity of the instrument; and (2) The Inner Model Test which is an assessment of the structural model to test the research hypotheses. The Outer Model Test is generally performed to ensure that the measurement is reliable and valid before making any conclusions about the relationships between constructs of the model. The measurement model can be tested by evaluating indicator reliability shown by FL value that should be at least 0.7 ; internal consistency reliability shown by Cronbach Alfa (CA) and Composite Reliability value should be at least 0.7 , convergent validity measured by Average Variance Extracted (AVE) that should be at least 0.5 [8], [9]. The FL values of items, CA, CR, and AVE values of all constructs resulted by SmartPLS fulfilled all the requirements. Thus, the measurement model of this study is valid and reliable.

The second step in using PLS is The Inner Model Test OR assessment of the structural model to test the research hypotheses. To test if the hypothesis is accepted or rejected can be measured by using path coefficient (PC). The path coefficients should have $\mathrm{t}$-values of at least 3.091, 2.576, $1.96,1.645,1.282$, and 1.036 respectively to be considered significant at the $99.9 \%, 99.5 \%, 97.5 \%, 95 \%, 90 \%$, and $85 \%$ confidence level one tailed test [8]. The t-Values can be obtained using re-sampling techniques, such as bootstrapping. Table III showed the path coefficients and tvalues of the model as a result of bootstrapping. All the paths are significant at the $99.9 \%$ confident level, except for the influence of Service Quality to System Use which has t value of 0.65 less than the $t$ value required. The result indicated that 4 hypotheses are significant and one hypothesis is not significant.

TABLE II: The PATH COEFFicIENTS AND T-VALUES OF THE MODEL

\begin{tabular}{|l|c|c|}
\hline Path & Path Coefficients & T-Value \\
\hline $\begin{array}{l}\text { System Quality to System } \\
\text { Use }\end{array}$ & $0.39^{*}$ & 5.31 \\
\hline $\begin{array}{l}\text { Information Quality to } \\
\text { System Use }\end{array}$ & $0.20^{*}$ & 3.91 \\
\hline $\begin{array}{l}\text { Service Quality to System } \\
\text { Use }\end{array}$ & 0.04 & 0.65 \\
\hline $\begin{array}{l}\text { Management Support to } \\
\text { System Use User }\end{array}$ & $0.35^{*}$ & 131.51 \\
\hline $\begin{array}{l}\text { System Use } \\
\text { Satisfaction }\end{array}$ & $0.94^{*}$ & \\
Note: *Significant Level 0.99 & & \\
\hline
\end{tabular}

\section{CONCLUSION}

Four out of five the hypotheses are supported by the data. The respondents of this study believe that system quality is the most influential factors that effect them to use Information System of Global Telent. They consider that system quality of Information System of Global Talent more than other factors when they wish to use the system. This 
finding is in line with the result of research by Blasini [11], Duangekanong [12], Gefferie [13] and Tzeng [14]. The second most important factor is management support. The respondents of this study believe that management support is one of key factors influencing the using of the system, which is in line with the results of Blasini [11], Duangekanong [12] and Rouibah et al. [15] The last factor is information quality. Information quality is positively influenced the using of Information System of Global Talent, indicating that the respondents believe that information quality is one of key factors influencing the using of Information System of Global Talent, which is in line with the result of research by Blasini [11], Duangekanong [12], Gefferie [13] and Tzeng [14].

\section{CONTRIBUTION OF THE STUDY}

The results of this study can be of a great value in the development of a theory regarding the evaluation of information system using a modified Updated DM IS Success Model. Management Support was confirmed as an independent variable that should be added to the original DM IS Success Model proposed by Delone \& McLean [3] as has also been confirmed by Blasini [11], Duangekanong [12] and Rouibah et al. [15] Such addition is still rare. Thus, this study fills the gap in the literature technology adoption using Updated DM IS Success Model.

Moreover, the findings of this study regarding evaluation issues on information system are significant from the perspective of business practice. The results of this study are expected to be of a great use to ABC company in its development of policies to enhance the adoption of Information System of Global Telent and to eventually increase the numbers of users and durations of using the system.

\section{REFERENCES}

[1] A. Sutanto and Indrawati, "Measuring global talent program satisfaction from Telkom Indonesia perspective," Learning Organization: Management and Business International Journal 2013, vol. 1, no. 1, December 2013.

[2] A. Sutanto and Indrawati, "The influence of decision makers' global mindset to the company's internationalization behavior (a case study of a Telkom's global talent program)," in Proc. the 3rd International Seminar and Conference on Learning Organization (ISCLO 2015).

[3] W. H. DeLone and E. R. McLean, "The Delone and Mclean model of information system success: A ten-year update,' Journal of Management Information Systems, vol. 19, no. 4, pp. 9-30, 2003.

[4] R. Weber, "Theory building in the information systems discipline: Some critical reflections," in Information Systems Foundations: Theory Building in Information Systems, D. N. Hart and S. D. Gregor, eds. ANU Press, 2012, pp. 1-20.
[5] B. W. Tjandra, Indrawati, and S. P. Rahayu, "The impact of system quality, information quality, and service quality to users satisfaction on knowledge management system (case study in kampiun system of telkom indonesia)," in Proc. the 1st Seminar and Conference on Learning Organization, Trans Luxury Hotel, Bandung Indonesia, December 4-5, 2003, pp. 123-138.

[6] Indrawati, S. Murugesan, and M. Raman, "A new conceptual model of mobile multimedia service (MMS) and $3 \mathrm{G}$ network adoption in Indonesia," International Journal of Information Science and Management (IJISM), 2010.

[7] A. N. H. Zaied, "An integrated success model for evaluating information system in public sector," Journal of Emerging Trends in Computing and Information Sciences, vol. 3, no. 6, pp. 814-825, 2012.

[8] Indrawati, Metode Penelitian Manajemen dan Bisnis: Konvergensi Teknologi Komunikasi dan Informasi, Bandung: Refika Aditama, 2015

[9] J. F. Hair, W. C. Black, B. J. Babin, and R. E. Anderson, Multivariate Data Analysis: A Global Perspective, New Jersey: Pearson Education, Inc., 2010.

[10] D. M. Levine, T. C. Krehbiel, and M. L. Berenson, Business Statistics A First Course, 4th ed. New Jersey: Pearson Prentice Hall, 2006.

[11] J. Blasini, "Critical success factors of process performance management systems: Result of an empirical research," in Proc. the 21st European Conference on Information Systems, 2013.

[12] S. Duangekanong, "Factors influencing the success of an ERP system: A study in the context of an agricultural enterprise in Thailand," Silpakorn U Science \& Technology Journal, vol. 8, no. 1, pp 18-45, 2013.

[13] D. C. Gefferie, "Evaluating the effectiveness of information systems on organizational performance in hospitals in suriname: A test of an extended version of delone and mclean's is success model 2003," Master Thesis, Maastricht School of Management, Netherlands, 2009.

[14] W. S. Tzeng, K. M. Kuo, H. W. Lin, and T. Y. Chen, A SocioTechnical Assessment of the Success of Picture Archiving and Communication Systems: The Radiology Technologist's Perspective, 2013.

[15] K. Rouibah, H. I. Hamdy, and M. Z. Al-Enezi, Effect of Management Support, Training, and User, 2009.

Indrawati was born in Indonesia and received her master degrees from Padjadjaran University (UNPAD), Indonesia, majoring in management. She received her Ph.D. in Faculty of Management, Multimedia University (MMU) Malaysia. Indrawati's research interests include adoption of services based on technology, competitive intelligent, innovation, new product development, new product acceptance, creative industry, Ecommerce, and smart city. She has published more than 300 articles in newspaper, tabloid, magazines, national (in Indonesia) and international proceedings and journals, as well as books. Several of her articles have got awards in several events, such as: the eight best articles on the 4th International Conference on E-Commerce with Focus on Developing Countries (ECDC), Kuala Lumpur Malaysia on 3-4 November 2009, the best paper on Smart Collaborations for Business in Technology and Information Industries (SCBTII) Conference, Bandung Indonesia August 15th -16th 2016, and the best paper on International Seminar and Conference on Learning Organization (ISCLO) 2016, Bandung Indonesia, October 26th 2016.

Lely Melia Kaniawati was born in Indonesia and received her master degrees from Telkom University (Tel-U), Indonesia, majoring in management. She was a participant of a Global Talent Program held by PT Telekomunikasi Indoensia, tbk in South Korea in 2013. 